\title{
Oral and literate traditions
}

Pieter J.J. Botha

Department of New Testament

Unisa

PRETORIA

\begin{abstract}
In this study the impononce of research concerning orality and oral traditions for a variety of pressing cument issues related to social history, cultural studies, education and science of religion is stressed. It is necessary to rake into account the full range of language use as it is spoken and listened to, read and written, 10 improve our descriptions and analyses of ways of communicating and consequently to uncover the inter-relatedness of language and culture.
\end{abstract}

\section{INTRODUCTION}

In one of his novels, Lawrence Sanders tells how the main character struggles to convince others of his suspicions concerning foul play. However, when he duly uncovers some bills and cancelled cheques, the reaction of a police detective is as follows:

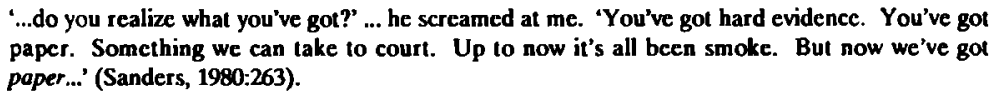

'...do you realize what you've got?' ... he screamed at me. 'You've got hard evidence. You've go paper. Somcthing we can take to court. Up to now it's all bcen smoke. But now we've got paper...' (Sanders, 1980:263).

In this scene we see something fundamental of contemporary Western attitudes: the dichotomisation of oral and literate traditions, and the extremely strong bias towards the written and the printed word. But, paradoxically, we are born into a cradle of sound; we usually only voice our deepest feelings and our most important relationships are sustained with spoken words. Our communications and our attitudes are much more complex than our professed bias implies.

In recent decades, in studies about language and communication, social scientists and particularly sociolinguists have begun to focus on oral and written texts and their forms and uses across contexts. The well known remark of Bloomfield (1933:21) "(w)riting is not language, but merely a way of recording language by means of visible marks" is no longer viable. A person may be the same no matter how you take his picture, but Bloomfield (1933:21) is wrong to extrapolate this to language: language is its 'picture' and the 'picture' is the language; the what and the how are inseparable. We have 
become more aware of the importance of the media of communication and the complexities of oral and literate traditions.

This article is based on the view that we can and should draw more on multi-disciplinary studies of oral and written language structures and uses. In fact, we must do so, for at least two purposes.

- Firstly, as education and literacy are inextricably linked to each other, we need coherent theories of literacy which "will have to account for the place of written language, both in relation to the forms of spoken language and also in relation to the communicative functions served by different types of language in different social settings in our culture" (Stubbs, 1980:15-16).

- Secondly, the importance of meaningful cross-cultural communication in our current situation cannot possibly be doubted. The need to take into account the full range of language as it is spoken and listened to, read and written in sociocultural contexts is self-evident. Orality studies will improve our descriptions and analyses of ways of communicating and of how oral and literate traditions relate to each other and other features of society.

\section{A MULTI- AND INTERDISCIPLINARY FIELD OF STUDY}

One of the consequences of extending one's scope of research to examine the relations between written and oral uses and structures of language is a multi-disciplinary link up with many other fields of study. Sociolinguistic interests have become standard features of the work of anthropologists (especially folklorists and social anthropologists), cognitive psychologists, social historians, discourse analysts, text linguists, literary theorists and students of religion.

In their work with oral texts (folklore, poetry, oratory, proverbs, riddles etc.) and how groups of people use and value these texts, social anthropologists have uncovered the different roles oral forms of knowledge play in societies. Working with the perspective that language both shapes culture and is shaped by it, a variety of studies have brought to light how the material equipment, the activities, interests, moral and aesthetic values of a culture correlate and interrelate with communicative realities (e.g. Bäuml, 1980; Hymes, 1975; Toelken, 1975; Goody, 1987; Vansina, 1985:94-185).

Social historians have raised questions about the consequences of the introduction and extension of literacy, often contesting popular notions about the beneficial effects of literacy for both individuals and groups (Graff, 1979, 1987a, 1987b; Street, 1984). 
Another instance of this rethinking brought about by historical investigation is the rediscription of the 'collapse' of the Middle Ages. 'Renaissance' appears to reflect not a quantitative revival of knowledge as such, but rather the collapse of social boundaries with regard to literate culture, and the disintegration of firm notions about a single 'truth' in society (Ward, 1990). Eisenstein traced the history of communications and cultural transformations in early modern Europe and concluded that the changes wrought by printing helped shift the confidence of men from divine causes to mathematical reasoning and man-made maps (Eisenstein, 1983:271).

Text linguists, discourse analysts and literary theorists have begun to challenge the supposed connections between a text and the reader's response, raising issues central to linguistic and anthropological study of language: to what extent do spoken and written versions of the same information differ? Do linguistic form and verbal style influence meaning and memory retention? (Tannen, 1980, 1982c, 1989; Olson, 1977; Ong, 1986). To what extent and with what effects are literate forms incorporated into oral societies in contact with literacy? What about the oral 'residue' of literate communication? (Bright, 1982, Cook-Gumperz \& Gumperz, 1981; Tannen, 1982b, 1988).

In the field of psychology, oral performances are examined for what they can reveal about the patterns of organisation of human memory (e.g. Stein \& Trabasso, 1982), but the complex issues of cognition and intelligence are also related to orality and literacy (e.g. Scribner \& Cole, 1981a). And, it has been claimed, one of the most important cultural factors in producing varying human attributes, both in mental health and illness, is the existence or lack of literacy (Carothers, 1959).

Ong (1977) has shown how almost all fundamental human questions can be rephrased in terms of orality-literacy tensions, an excellent way of illuminating the extent of this problem (cf. also Ong, 1987). Another way of illustrating the importance of orality studies is by reflecting on the concept voice. Voice is the very essence of language, the substance of human interaction. A text simply lies there, waiting for voice. Voice creates the space-time in which we - as humans - exist: to claim consciousness is to arouse voice.

As in all matters human, profound paradoxes are connected to voice. Voice unifies, and yet the history of the voiced word is tied up with all human conflicts. Voice is not merely linked to social structures, but chiefly to the deeply personal, to subjectivity and intersubjectivity, where the physical and the psychic merge. Voice emerges from the body but represents all that is not-body. One ascribes to it material qualities such as tone, timbre, volume, pitch and range, but it is also an archetypal psychic symbol. It is essential for language, but extends beyond language to the direct, inarticulate 
expression of emotion. It is as archaic as humanity itself, yet always up-to-date, combining freely and creatively with advanced technologies.

It is also a very neglected field of study - to our detriment.

\section{COGNITIVE AND LINGUISTIC FEATURES}

The very cognitive structure of the individual human being and the formal patterns of human social relations are intimately linked to the forms of communication that are predominant in given eras. An oral culture, without writing, print or electronic media, seems to be 'biased' toward a particular pattern of sensory and expository capacity that encourages ways of seeing, hearing, and knowing that are remarkably different when other forms of communication are more prominent. Over time those tendencies seem in turn to favour and encourage major changes in social organisation, influencing, to a greater or lesser extent, possibilities regarding political, legal, religious, and economic structures. Goody $(1977,1986,1987)$, in particular, has investigated the impact of writing on societies (such as in the ancient Near East and in contemporary Africa), showing how changes in the mode of communication affect general features of social systems. Human experience seems to depend greatly upon the form or forms of communication used and valued by various human societies.

In the pursuit of an understanding of the links between communication and culture, various foci of attention have dominated research.

\subsection{Orality, writing, cognition and knowledge}

Oral culture functions on the basis of practical experience, memory and performance skills. People raised in oral cultures perceive the world in terms of immediate and concrete experience, specific situations they face daily. They interpret new events or statements in terms of the specific contexts and objects around them, the settings, people, and tools that make up their daily existence (for these, and the following considerations see Carney \& Zajac, 1977:1-73; Goody, 1977:36-51, 1989; Säljö, 1988; Ong, 1986, 1982:30-77; 1988; Lord, 1987a).

Human culture presupposes technical skills and crafts. In an oral world the sophisticated skills developed in craftsmanship are passed on from one person to another in apprenticeships or face-to-face instruction. Many of the great works of ancient architecture, art, and even literature, were developed in this way without the assistance of writing (cf. Couch, 1989). In fact, even when familiarity with writing develops, active 
disregard or suspicion of the utility of writing is often expressed. Writing is not an inevitable, or even necessarily a desirable end in itself: writing is deemed inferior to oral teaching by many societies.

For I did not imagine that things out of books would help me as much as the utterances of a living and abiding voice. ${ }^{1}$

In orally based societies traditions and events are preserved and passed on through oral performance. Useful words and events are retained very long, while less important words or events fade from memory through lack of repetition or recall. People in an oral culture develop and cultivate oral performance skills, speaking and singing to each other for both pleasure and practical gain. They are not, however, easily able to abstract themselves from their own existence to imagine the point of view of another. Although they create complex cultural structures and works of art, their skills in practical craftsmanship, oral performance, and memory remain the foundation of their culture.

Literacy becomes influential due to its power as a support for, or alternative to memory. Writing preserves words or events verbatim and indefinitely. It is, however, much more than a mere recording device.

Writing constantly reinforces the awareness of symbolic, abstract relationships. Writing is the symbol for the spoken word, which symbolises thought. Through writing, one can be confronted with one's own thinking without the physical presence of other humans. People grow aware of categories as they reread and study relationships between written words - words writing has removed from the intonation and situations that make them vocally concrete and contextually specific. Rereading and revising versions of texts develop awareness of abstract relationships between categories. Use of the linear sentence encourages the focus on cause-and-effect relationships between things. This reinforcement led, for example, to Aristotle's concern with categories and the relationships between them (Lentz, 1989:165-174) - a concern that eventually formed the basis of Western scientific thinking. The frequent use of these abstractions cultivated the ability of people to project themselves imaginatively into situations beyond their experience with the concrete world around them.

Facilitated by writing, the ability to envision other points of view is enhanced. The oral mentality is, simply, unaware of itself through its inability to look at itself from

1 Papias, bishop of Hierapolis early 2nd century, as quoted by Eusebius (Historia Ecclesiastica 3.39.4). Plato expressed some famous, and thought provoking, skeptical remarks concerning writing: Epistulae 7.340-345, Phaednus 269-276. 
without. ${ }^{2}$ Writing helps the development of self-consciousness, the awareness of the individual as one who makes decisions, acts upon them, and takes responsibility for the consequences.

\subsection{The distinctiveness of orality}

The fundamental question underpinning this type of research is: is there a specific oral poetics? This is an extremely difficult and complex question to answer. In the wake of McLuhan's book (1962 - not an overly readable text, but many useful insights; $c f$. Steiner, 1985:280-286) a variety of theories have been formulated.

The initial principle can be simply stated: a message does not reduce to its obvious content, but carries with it a latent content constituted by the medium that transmits it. The introduction of writing in a society corresponds, then, to a deep-seated mutation of a mental, economic and institutional order. A second rupture occurs, albeit less markedly, when manuscriptural writing passes to printing; and a third occurs as mass media begin their dissemination. These concerns have been taken up by Ong in his various publications $(1967,1977,1982,1986)$.

In the McLuhan perspective two types of civilisations are opposed. In a universe of orality, human beings internalise their experience of history without conceptualising it; they conceive of time in circular patterns. Space is conceived as a dimension of nomadism, and collective norms usually determine behaviour. The use of writing, on the other hand, implies a disjunction between thought and action, a deep-seated nominalism, the predominance of a linear conception of time and a cumulative notion of space, individualism, rationalism and bureaucracy. This paper adopts this perspective, but not without accepting a number of attenuations and with emphasis on certain nuances. An important reason for accepting this perspective is its illuminative power, both for understanding human diversity and for better, more comprehensive historical insight.

Despite the clear validity of the premises and the general verisimilitude of the theory, many questions remain unanswered. The oral/written dichotomy can be maintained only at a high level of generality. At a historical level, these terms appear to be

2 One peasant responded to a researcher, when asked to describe himself: "What can I say about my own heart? How can 1 talk about my character? Ask others; they can tell you about me. I myself can't say anything". (Cited by Ong, 1982:55.) 
extremes in a continuous series (Tannen, 1982a; Finnegan, 1974, 1988:175; Goody, 1989:226-227; Akinnaso, 1982, 1985; Bright, 1982). The majority of features are not only differences of degree, of one more or one less, but they coexist and collaborate in every age among all people. ${ }^{3}$ In a sense there is an artificiality to any generalisations about oral versus literate cultures. Not only are there continua of oral and literate habits across cultures, but there is no unilinear development in the practice of oral and literate traditions.

Yet, given the immense complications, oral-literate dynamics have proven to be not only quite resilient under investigation, but have also provided a perspective of immense value. 4

\subsection{Orality and memory}

Sociolinguists studying the organisation of oral texts have joined with literary theorists and cognitivepsychologists to focus on the role of memory in narrative recall in oral and written forms. This research has its roots in attempts to understand the ways in which oral epics were composed and transmitted. Lord (1960), building upon the work of Parry (1971, who was influenced by Jousse (1990), originally published in French 1925), posited that the singers/reciters of epics remembered and recomposed their epics, not word by word, but by formulae. The so-called Parry-Lord hypothesis, or oral-formulaic theory, has exerted an incalculable influence (cf. Foley, 1988). Subsequently, linguists, anthropologists and sociolinguists have considered the structures of formulae and their combinations to explain oral texts from Homer to current African, European and Asian societies (Stolz \& Shannon, 1976; Finnegan, 1970, 1977; Foley, 1985; Lord, 1987b), as well as biblical and other religious texts (Culley, 1976; Botha, 1991; Graham, 1987).

This vein of research is basically an explication of the (much neglected but nevertheless important) insights of Marcel Jousse, who so eloquently described the 'oral

3 To realise how complex things really are, one need only ask: What exactly is writing? Megaliths, property markers, African masks, tattoos, social symbols - does all that fall under writing? Consequently many "of the standard comparisons between oral and literate cultures are nawed because the role of writing is misrepresented- (Goody, 1989:226). Sec further Schmandt-Besserat, 1977; Harris, 1986; Davies, 1986; Goody 1987:3-54.

4 See, e.g., Anyidoho, 1983; Botha, 1990; Chesebro, 1984; Couch \& Chen, 1988; Finnegan, 1988; Goody \& Watt, 1963; Goody, 1986; Havelock, 1963; 1982; 1986; Haynes, 1988; Kaplan, 1989; Michaels, 1985 
style' and the connections between memory (without external aids such as writing) and the psycho-physiology of gesture: how repetition, verbal parallelism, rhythm, mnemotechnical recitative devices, bodily motions and mimicry combine to distinguish oral communication from the written style. Jousse worked with the perspective that "human expression was gestural expression, that man did not first express himself with his mouth, but with his entire body, and with his hands" (Jousse, 1990:xiv).

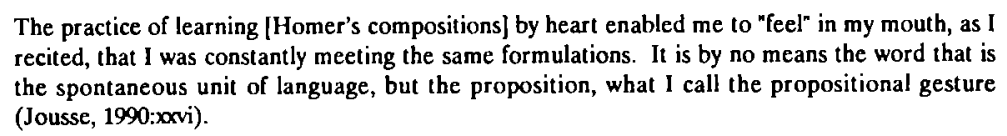

Similar principles of memory and communication (but interwoven with literacy practices) are evident in mainstream, literate societies in which children hear bedtime stories from an early age and are asked teaching-questions about these stories. These children recall stories according to a basic schema and their telling and writing of stories quickly match the well-formed models of narratives read to them before school and read by them in school (Heath, 1982:51-56; cf. also Stein \& Trabasso, 1982:261). Formulaic openings, fairly standard orientations to characters and settings, and stylised evaluations of the content develop with their retelling of narratives.

\subsection{Literate thought and action}

In the modern Western frame of reference, there is a basic identification of text (or communication) with writing, or, more precisely, with print, in its most concrete, reified sense.

In this view, a text is a written or printed document to which the basic access is through an individual's private, silent reading and study. To this way of thinking, the fixed, visible page of print is the fundamental medium of information, hence a particular view of knowledge: to a degree unknown in any other culture or history, knowledge has become 'book learning'. Writing has turned into the basic form of language: "... the speaker or writer can now hardly conceive of language, except in printed or written form; ... his idea of language irrevocably modified by his experience of printed matter" (Chaytor, 1950:6). Consequently, we, as part of the literate West, have lost awareness of the essential orality of language (cf. Ong, 1982:8; Havelock, 1982:50).

The custodians of learning in our culture have been especially prone to exalt the written or, even more, the printed word as the chief bulwark of learning and progress. 
The "relentless dominance of textuality in the scholarly mind is shown by the fact that to this day no concepts have yet been formed for effectively, let alone gracefully, conceiving of oral art as such without reference, conscious or unconscious, to writing" (Ong, 1982:10). Printing goes hand in hand with the values of modern, 'scientific' scholarship: the suspension of subjective emotions and personal involvement in favour of objectivity and visual verification (values essential to experimental science), leading to 'the cult of the positive, the exact, and the predictive' and the fervent paying of 'tribute to the mirage of mathematical exactitude and predictability.'5 Printing allows the experience of rapid and easy access to quantitative information (so-called raw data) which is observed and analysed.

'Objectivity' has been an especially important value in modern Western thought. With scientific detachment have come, however, other kinds of detachment and, generally, an increased objectification of the world around us (Ong, 1986; 1990). The virtually endless replicability made possible by the printing press adds greatly to the sense of the reliability and objective neutrality of the written word. With print, words and books lose their dynamism and personal quality and become things themselves: mass-produced, impersonal objects. The printed word appears to be so much more sure, fixed, and unambiguous than the merely spoken or even written word! As such printing contributes to the illusion of neutral bearers of objective content accessible to any literate person who can understand that content.

Thus, it is no cause for wonder that the whole trend of education in the post-Enlightenment West, especially in this century, has been away from memorisation (essentially an oral activity), reading aloud - together with reciting by heart and declamation - and rhetoric, which formerly was the core discipline of literate culture and education (Ong, 1982:108-112; Sloan \& Perelman, 1986:803-808; Kennedy, 1980). In their place has come ever greater emphasis upon swifter, more efficient comprehension of printed texts by the silent, scanning reader, and increased reliance upon reference aids and massive information storage of all kinds. The anonymous and impersonal, universally accessible, and 'independently verifiable' word of the printed book, which was the first truly mass-produced commodity in history (McLuhan, 1962:124-125), is the backbone of Western scholarship and of modern, technological society as a whole. Literacy has

5 An adaptation of the descriptions of Steiner, 1985:36-38. Steiner castigates historians and sociologists for submitting to the temptation of equating scientific rigour with mathematics and consequently to falsely believe in impartiality. The result is anti-literacy, science promoting inhuman and unhuman literacy. 
influenced Western philosophy profoundly, being a major precondition for hermeneutics. "The development of a distinction between statements and texts on one hand and their interpretation on the other was a consequence of literacy" (Olson, 1988:126).

\section{THE SOCIAL CONTEXT}

The significance of a consistently contextual approach to the study of communication is a major concern of Hymes, and has been recommended by him in many publications (e.g. Hymes, 1964; Hymes calls his approach an ethnography of communication). An ethnography of communication studies oral and written traditions in specific communities and goes to great lengths to be aware of the relevant contexts of communication. It describes the boundaries of the physical and social community in which communication is possible, the limits and features of communicative situations, the patterns of choice of speakers, listeners, writers and readers, and the values the choices among styles, occasions and content of written and spoken language, carry within the speech community.

In an examination of the oral and the written uses of language in three communities in the south-eastern part of the United States, Heath (1983) shows the deep cultural differences between various groups in almost all aspects of their uses of language, from the early reading and writing experiences of children to adults' ways of viewing information given in written and oral forms.

In the working-class communities, particularly where black families were concerned, written materials were most often used to support memory or confirm information already established through oral channels. Reading and writing were public social activities, the meanings of which were shared and negotiated socially: one person read, while others interpreted by contributing their experiences to reach consensus on meaning. In the white working-class community, reading was a private activity, and only certain persons were designated to read aloud and interpret for others the meaning of the written words. Both communities read only a few minutes a day, and most of this reading focused on instrumental or confirmational goals - to gain information for practical needs or to check or confirm certain facts, such as dates, addresses, some appointments, etcetera. Almost no writing was done in either community, except lists or jotted notes used to support the memory of certain isolated bits of information. Writing in both communities was regarded as an activity by groups outside the working class community, and people felt that writing, unlike reading, did not need to be done by them. For those special occasions when writing was required, 
they could go to certain individuals within the community or to professionals outside their social group. For neither community were there occasions to read or write extended prose in their work settings. In their social and economic environment few jobs require any but the most minimal reading and writing; instead, employers want logical thinking, rapid interpretation of oral directions, and predictability in performance of basic mathematical skills. Numeracy, organisational skills and the ability to stick to a job were far more often required in many working-class jobs than reading and writing skills per se. In this setting many institutions have unconsciously adopted the policy of having within their midst 'scribes' who carry out most of the writing tasks of the organisation, while others bear most of the responsibility for the interpretation of written materials.

The two working-class groups differed as strikingly from each other as either did from the pattern of the mainstream blacks and whites who held power in the schools and workplaces of the region. The mainstream families oriented their children at an early age into both reading and writing, focusing on isolated discrete parts of texts and leading their children through teaching-questions to talk about the arbitrariness of pictures and words, the decontextualisation of information in books from 'real' life, and the autonomous authoritative status of written materials. On their jobs, many men and women of these communities served as scribes, reading and writing for the institution as a whole or for specific individuals within the institution. At home, many often read and wrote prose, and they frequently used written materials for recreational or critical purposes.

Researchers have examined in both laboratory and naturalistic settings the telling and writing of texts (usually stories) by adults and children. These studies illustrate the wide differences between judgments cross-culturally on appropriate styles for presenting the same information either orally or in written form (Olson, 1980; Chafe, 1980; Hildyard \& Olson, 1982; Olson \& Hildyard, 1983). For mainstream members of highly literate societies, oral texts tend to be longer than written texts, and when retelling stories they prefer to present themselves as acute recallers (or good experimental subjects). Drawing on schooling experiences they tend to treat texts as decontextualised objects. In contrast, members of orally oriented societies tend to draw upon interactive experience which was more focused on interpersonal involvement. They prefer to present themselves as good storytellers and acute judges of human behaviour; their oral texts tend to be shorter and thematically constructed (Tannen, 1980). 
What this, and similar research reveal is the enormous value of a historical and contextual approach to literate and oral traditions. Without the social fabric in which our activities are embedded there can be no talk of meaning or understanding. To investigate our communicative activities - and consequently our very humanity - we need to probe the use of language in contexts of situation, so as to discern bundles or patterns of relationships, patterns that escape separate studies of linguistics, of personality, of social structure, religion and so forth, each abstracting speech and writing into some other frame of reference. We should take as context a community or network of persons, investigating its communicative practices as a whole, showing how any use of channel or code functions as part of the resources upon which the members draw.

\section{THE TEACHING OF LITERACY}

Any discussion of literacy should start with a reference to the provocative work of Harvey Graff who very effectively challenges current assumptions about the necessity and benefits of literacy. Graff has carefully built a series of arguments which can in summarised form be restated as the literacy myth: Western societies have misunderstood the nature of literacy and the role it plays (or can play) in the life of the individual and society. That misunderstanding, which can be explained historically, has determined the way in which 'literacy crises' are conceptualised and acted upon in various Western societies (Graff, 1979, 1987a). Graff (1987b) has also provided us with a full-fledged history of the nature and spread of literacy from the earliest times to the present. The history of literacy in the West is rather one of contradictions and continuities than that of a progressive, uniform development that immediately and distinctively separated it from other forms of communication. An over reliance on literacy as a solution to profound social problems has been at best misguided and at worst a disaster.

The basic insight which Graff provides is the recognition of literacy as the acquired technology that it is. It is not a mechanism for creating other socially desirable characteristics - although it has often served as a disguise for them. Literacy does not automatically bring moral improvement with it; Graff argues that it does not bring economic or personal improvement either - although its proponents have long claimed that it does. We find that literacy more often than not has helped to create distressing and painful gaps between different generations (Graff, 1987b:276). "The penetration of literacy into an overwhelmingly oral, native culture tends to cause massive social, religious, ideological, political, economic, and cultural changes" (Graff, 1987b:380). 
Even more importantly, the fatal flaw in the modern view of literacy - its assumed beneficial results for states, societies, and individuals (1987b:261) - can, and usually does, place literacy in the service of shaping a "controllable, docile, respectful work force, willing and able to follow orders" (1987b:262) and serves to confirm "an ordained and approved social code" (1987b:263)6.

In this context, reference should be made to the work of Paulo Freire (1972; 1976). With locally based, informal instruction in small groups with active roles for learners and relevant, experiential text content, remarkable success in improving literacy has been achieved. This approach, in which learners play a major role in shaping the programme, has been far more effective than so-called modern, Western formal institutional schemes. Freire's critique of political oppression and his emphasis on the use of generative learning as a path to political and cultural freedom are attractive to various political groups, particularly those with socialist inclinations. Through the achievement of active, partially self-taught literacy, rooted in dialogue and new visions of the world, persons presumably are able to transcend the limits of their former social, political and cultural conditions. Literacy is a method, not an end: 'conscientization' is the goal (cf. Mackie, 1980).

These contributions compel us to realise that not only has literacy provided no solution to basic structural problems of modern capitalist societies; it has led us to undervalue other skills that may be as valuable to the individual, no matter how deprived, as the individual's literacy may be to society as a whole. In short, we become aware that literacy has far more often been used on people than it has for them.

Before simply plunging into so-called literacy promotions, we should ask the larger and more complex questions about what we think literacy is and what it should be, to what ends literacy is necessary, and by whom and why it is required.

Literacy is not something neutral or innocent. Russel Means, an American Indian activist, comments:

My culture, the Lakota culture, has an oral tradition, so I ordinarily reject writing. It is one of the white world's ways of destroying the cultures of non-European peoples, the imposing of an abstraction over the spoken relationship of a people.

6 Cf. the perspective of Lévi-Strauss (1974:299): "My hypothesis, if correct, would oblige us to recognize the fact that the primary function of written communication is to facilitate slavery. The use of writing for disinterested purposes, and as a source of intellectual and aesthetic pleasure, is a secondary result, and more often than not it may even be turned into a means of strengthening, justifying or concealing the other." 


\begin{abstract}
So what you read here is not what I've written. It's what I've said and someone else has written down. I will allow this because it seems the only way to communicate with the white world through the dead, dry leaves of a book. I don't really care whether my words reach whites or not. They have already demonstrated through (heir history that they cannot hear, cannot see; they can only read. (Quoted by Gill, 1987:133-134.)
\end{abstract}

Literacy is a vast and immensely complex issue, ${ }^{7}$ and in our country its problems and failures are exacerbated by a macro society in upheaval and group tensions due to political, economical and cultural diversity as well as various levels of technological awareness.

Taking oral-literate dynamics into account allows one to be sensitive to cultural differences. Enculturation starts from birth. In an interesting cross-cultural study, Heath (1982) illustrates the effect of growing up in a worker society where literacy events and literate attitudes differ considerably from 'mainstream' groups. As babies these children are encapsuled "in an almost totally human world, they are in the midst of constant human communication, verbal or nonverbal" (Heath, 1982:64). Though skilful storytellers and adept at analogical reasoning, when they go to school "they face unfamiliar types of questions which ask for what-explanations" (Heath, 1982:69). By the time in their school career when reason-explanations and affective, creative comparisons are called for,

\begin{abstract}
... it is too late for many Trackton children. They have not picked up along the way the composition and comprehension skills they need to translate their analogical skills into a channel teachers can accept. They seem not 10 know how to take mcaning from reading; they do nol observe the rules of linearity in writing, and their expression of themselves on paper is very limited. Orally taped stories are of en much better, but these rarely count as much as written compositions. Thus, [they] ... continue to collect very low or failing grades, and many decide by the end of the sixth grade to stop trying and turn their attention to the heavy peer socialization which usually begins in these years (Heath, 1982:70; 1983:113-148, 166-211).
\end{abstract}

\title{
6. SACRED WORD AND SACRED TEXT
}

There is a functional diversity of scripture, both as a specifically Christian or Jewish phenomenon and as a generic concept in the history and science of religion, that often

7 See, amongst many possible references: Resnick \& Resnick, 1977; Stubbs, 1980; Akinnaso 1981; Cook-Gumperz \& Gumperz, 1981; Scribner \& Cole, 1981a, 1981b; Graff, 1985; CookGumperz 1986; Baumann, 1986; Luke, 1989; Ogbu, 1990; Street, 1984; 1988. The implications and possibilities of the relationships between (electronic) technology and literacy add further complex dimensions: Nickerson, 1985; Smith, 1986; Ong, 1982:135-138; Noblitt, 1988. 
remains unnoticed. This neglect is evident in the common acceptance of a definition of 'scripture' that rarely (if ever) goes beyond 'sacred book' in the sense of a written or printed text only.

This kind of objectification has a severely limiting influence on one's perspective on and understanding of religious experiences and activities. A more comprehensive awareness of orality (or voice) leads to a functional or 'relational' understanding of scripture, and helps to realise the degree to which written scriptural texts function as an oral-aural text in all but the most recent period of modern Western cultural history.

A specific instance of this bias has been uncovered by Gill (1987), who shows how the academic definition and study of religion are determined by the presence or absence of writing. Gill develops an extensive argument through an interpretive study of Native American religions to show that our usual approaches to the study of religion are "largely unusable and inadequate" (1987:6) because we are ill-equipped to deal with nonliterate or preliterate religious experience (see also Tedlock, 1983, particularly pp. 178-193 and 233-246).

\subsection{Scripture as written text}

The ubiquitousness of religious traditions in human societies, and the fact that sacred words are usually the first to be written down, make them particularly useful examples of the complexities and ambiguities of literate traditions. Written religious texts have virtually always enjoyed a special status in societies. With the notable exceptions of classical Greece and India, the writing down of a sacred text has from ancient times lent it special authority and made it often even an object of overt veneration.

The very familiarity with which we move among books and the ubiquitousness of printing has bred in us its own kind of contempt. We have little access to the sense of awe and respect before the physical copy of any text that prevailed in ages (and even today prevails) in places in which a book was or is a rare thing, and a scriptural text often the only book. The devotion of illiterate and preliterate people - who have been the majority throughout history - in the presence of holy writings can scarcely be envisaged by us (Graham, 1987:46).

Written fixation of central religious traditions enhances their status as visible heritages of the past and physically present sources of guidance. The very permanence and fixity of the written (or copied) page lends credence to the idea that its sacred words have always existed and always will. 
There are numerous examples of traditions in which the written fixation and transmission of religiously significant and authoritative texts have been crucial to the definition and sustaining of the traditions themselves. The rise and impact of Protestantism comes to mind, or the effect of writing and the Confucian tradition in Classical China. In the Hellenistic world we can follow the cumulative development of the importance of written texts that were considered to be 'classics' or 'scriptures' of various kinds. The culmination of this development seems to have come in the Christian movement, with its eventual development of the biblical canon (Graham, 1987:60). Even in traditions where great emphasis is placed on memorising and reciting, such as the Rabbinic Jewish and Therevada Buddhist, the fixing of a written canon shows how important to a tradition the delineation of 'holy writing' can be.

The most common explanation for the special treatment and status of the written (sacred) word has been the common perception of the permanence and objectivity of writing. However, and particularly in popular culture, writing can sometimes be seen as possessing an inherent power: "Strictly, then, writing is a charm: written signs are charms" (Van der Leeuw, 1964:435; cf. the prescriptions in Numbers 5:23-28). The power of the living word persists in the characters written down, and can even be experienced as magic: "one method of gaining power of the living word ... Committing sacred texts to writing therefore was ... intended to ... attain power, since with the written word man can do just what he will" (Van der Leeuw, 1964:435-436).

Certainly the magical or quasi-magical quality of the written word is abundantly visible in the popular use for divination and talismans of copies of sacred books. The Sikh veneration of the Granth Sahib is a prime case in point, as is Tibetan Buddhist reverence for the physical copies of the sutras. Certain forms of (fundamentalist) Protestant Christian treatment of the Bible can rightly be termed bibliolatry. Jewish, Islamic and Mormon reverence for their particular holy writings is also a well-known fact of religious practice and piety.

Yet, the reverence for the written word goes beyond the purely magical. It is also though only in part, the result of a desire to set such texts apart from all other forms of communication in definitive, tangible ways. This seems to have been a major motivation for the early Christians' appropriation of the little-used parchment codex, which they made their distinctive vehicle for their authoritative traditions (Roberts \& Skeat, 1983:54-61). The elaborate care given to the copying and ornamentation of both early 
and later Bible manuscripts testifies to an experience of the Bible as holy object (cf. Troll, 1990). Such pious copying and illumination of sacred texts is widespread. We need think only of the staggering variety and artistry of Qur'an calligraphy and illumination, or the reverent artistry with which synagogical copies of the Torah are prepared among Jews.

\subsection{Scripture as spoken word}

As a physical entity, scripture is a familiar phenomenon to Western literates, and it is this aspect of scripture upon which modern scholarship has focused virtually all of its attention. The reasons for this orientation are not difficult to perceive. We are part of a particular historical and linguistic situation that has developed a massively one-sided orientation. The immense importance that we attach to writing and the written or printed word naturally bolsters our conception of scripture as written. We automatically assume that the use of terms such as scripture, word of God, holy writ, etcetera refers to a printed or written artifact, and that this conceptualisation is applicable to any and all sacred texts around the world. We need a conscious adjustment of perspective for meaningful contact with other religions, such as those of African people.

Religion in African societies is written not on paper but in people's hearts, minds, oral history, rituals and religious personages like the priests, rainmakers, oflicialing elders and even kings. Everybody is a religious carricr (Mbiti, 1990:3).

Furthermore, almost all forms of piety have in some sense or another oral aspects. In fact, for most of history, and even for major sections of most contemporary societies sacred texts have been and are memorised and recited, something that one lives with orally and aurally. The recognition of the importance of oral speech and the oral sacred utterance is a major challenge for historical understanding, but even more so for cross-cultural communication.

The experience of the dynamic power of verbal communication, the centrality of the words of myth and ritual, is due to the sense of the spoken word as something alive with almost magical or transcendent power. In orally based cultures, word and act are not to be separated. Speech is action and a word has life and power: whoever utters words sets power in motion (Van der Leeuw, 1964:401-407; Tambiah, 1985).

Consequently, there is much to be said for the perception that in the cult-oriented world of oral traditions, and to a lesser degree in any ritual activity, the act of naming makes present, or at least summons the power of, that which is named. 
This is particularly well illustrated in the baptism practices of the African Independent Churches, where the pool selected (whether a river, stream, dam or mere pan of mud water) is experienced, for the duration of the ceremony, to be the Biblical Jordan and the immersion itself to be a re-enactment of the kind of baptism Jesus experienced (Daneel, 1984).

Another instance of the potency of spoken words is "the vast powers which always emanated from such cult terms as Hallelujah, Kyrie eleison, Amen, Om; a mystical tonecolour is attached to them, while their very incomprehensibility enhances their numinous power" (Van der Leeuw, 1964:405-406).

The importance of the oral word and its power are not of course limited to nonliterate or archaic stages of culture or religion. Truth is often experienced as bound up with the spoken word, whether that of a divinity or that of a human teacher or sage. In theocentric traditions, scripture is the place where God speaks to humans, usually through another human or by reading and reflecting, that is, in soliloquy. Often, it is in the exposition of scripture that the wisdom heard and taught by generations of prophets or spiritual teachers is recorded, and in the ongoing tradition of oral teaching, scripture comes alive as the sacred word of truth spoken. An example is the usage of So spreek die Here! which is so characteristic of the liturgy of the Dutch Reformed Church.

\section{CONCLUSION}

Instead of simply assuming writing and speech to be unchanging or having little significant differences, we should be aware that our communicative activities are social constructs. Like our other attempts at interpretation, understanding oral and literate traditions should not be ethnocentrist nor unhistorical.

Nowadays, in one way or another, voluntarily or involuntarily, we all participate more or less in oral and literate traditions. Adopting the perspective or oral-literate dynamics can contribute to critical and meaningful articulation of how communication echoes culture, and how speech and writing manipulates the representation of reality. One can even expand this claim to the proposal that the concept voice provides a common ground for the social and human sciences.

Extending our consciousness in this sense allows self-criticism, putting literacy in its place'. As literates, we should heed what nonliterates have to say about our 'bookishness' (as summarised by Gill, 1987:136): 
They note the tendency toward abstraction and depersonalization that may accompany writing. They point out that writing and reading may remove one from the immediacy of experience particularly social experience. They point out that writing permits one the avoidance of responsibility, the false luxury of never having to learn, the possibility of detachment - all of which, from their point of view, amounts to a loss of meaning and a threat to existence.

\section{REFERENCES}

AKINNASO, F.N. 1981. The Consequences of Literacy in Pragmatic and Theoretical Perspective. Anthropology and Education Quarerly, 12:163-200.

AKINNASO, F.N. 1982. The Literate Writes and the Nonliterate Chants: Written Language and Ritual Communication in Sociolinguistic Perspective. (In Frawley, W., ed. Linguistics and Literacy. New York : Plenum Press. pp. 7-36.)

AKINNASO, F.N. 1985. On the Similarities between Spoken and Written Language. Language and Speech, 28:323-359.

ANYIDOHO, K. 1983. Oral Poetics and Traditions of Verbal Art in Africa. Ann Arbor : University Microfilms International

BAUMANN, G. ed. 1986. The Written Word : Literacy in Transition. Oxford : Clarendon.

BäUML, F.H. 1980. Varieties and Consequences of Medieval Literacy and Illiteracy. Speculum, 55:23765 .

BLOOMFIELD, L. 1933. Language. New York : Henry Holt.

BOTHA, P.J.J. 1990. Mute Manuscripts: Analysing a Neglected Aspect of Ancient Communication. Theologia Evangelica, 23(3):35-47.

BOTHA, P.J J. 1991. Mark's Story as Oral Traditional Literature: Rethinking the Transmission of Some Traditions about Jesus. Hervonnde Teologiese Studies, 47(2):304-331

BRIGHT, W. 1982. Literature: Written and Oral. (In Tannen, D., ed. Analyzing Discourse: Text and Talk. Georgelown : Universily Press. pp. 271-283.)

CARNEY, T.F. \& ZAJAC, B. 1977. Communications and Society. A Social History of Communications. Winnipeg : University of Manitoba.

CAROTHERS, J.C. 1959. Culture, Psychiatry, and the Written Word. Psychiatry, 22:307-320.

CHAFE, W. ed. 1980. The Pear Storics: Cognitive, Cultural and Linguistic Aspects of Narrative Production. Norwood: Ablex.

CHAYTOR, H.J. 1950. From Script to Print: An Introduction to Medieval Vernacular Literature. Cambridge : Heffer.

CHESEBRO, J.W. 1984. The Media Reality: Epistemological Functions of Media in Cultural Systems. Critical Studies in Mass Communication, 1(2):111-130.

COOK-GUMPERZ, J. ed. 1986. The Social Construction of Literacy. Cambridge : University Press.

COOK-GUMPERZ, J. \& GUMPERZ, J.J. 1981. From Oral to Written Culture: The Transition to Literacy. (In Whiteman, M.F., ed. Writing: The Nature, Devclopment, and Teaching of Written Communication, vol 1. Variation in Writing: Functional and Linguistic-Cultural Differences. Hillsdale : Lawrence Erlbaum. pp. 89-109.)

COUCH, C.J. 1989. Oral Technologics: A Cornerstone of Ancient Civilizations. Sociological Quarterly, 30(4):587.602

COUCH, C.J. \& CHEN, S.L. 1988. Orality, Literacy and Social Structure. (In Maines, D.R. \& Couch, C.J., eds. Communication and Social Structure. Springfield : Charles C. Thomas. pp. 155-171.) 
CULLEY, R.C. 1976. Oral Tradition and the OT: Some Recent Discussion. Semeia, 5:1-33

DANEEL, M.L. 1984. Life Around the Pool in African Independent Churches. (In Hofmcyer, J.W. \& Vorster, W.S. eds. New Faces of Africa. Pretoria : University of South Africa. pp. 36-79.)

DAVIES, A.M. 1986. Forms of Writing in the Ancient Mediterranean World. (In Baumann, G, ed. The Written Word: Literacy in Transition. Oxford : Clarendon. pp. 51-77.)

EISENSTEIN, E.L. 1983. The Printing Revolution in Early Modern Europe. Cambridge : University Press.

FINNEGAN, R. 1970. Oral Literature in Africa. Oxford : Clarendon Press

FINNEGAN, R. 1974. How Oral is Oral Literature? Bulletin of the School of Oriental and African Studies, 37:52-64.

FINNEGAN, R. 1977. Oral Poetry: Its Nature, Significance and Social Context. Cambridge : University Press.

FINNEGAN, R. 1988. Literacy and Orality: Studies in the Technology of Communication. Oxford Blackwell.

FOLEY, J.M. ed. 1985. Oral-Formulaic Theory and Research: An Introduction and Annotated Bibliography. New York: Garland.

FOLEY, J.M. ed. 1987. Comparative Research on Oral Traditions: A Memorial for Milman Parry Columbus : Slavica Publishers.

FOLEY, J.M. 1988. The Theory of Oral Composition: History and Methodology. Bloomington : Indiana University Press.

FREIRE, P. 1972. The Pedagogy of the Oppressed. Harmondsworth : Penguin.

FREIRE, P. 1976. Education: The Practice of Freedom, London : Writers' and Readers' Publishing Cooperative.

GILL, S. 1987. Native American Religious Action: A Performance Approach to Religion. Columbia : University of South Carolina Press.

GOODY, J. 1977. The Domestication of the Savage Mind. Cambridge : University Press

GOODY, J. 1986. The Logic of Writing and the Organization of Society. Cambridge : University Press.

GOODY, J. 1987. The Interface between the Written and the Oral. Cambridge : University Press.

GOODY, J. 1989. Oral Culture. International Encyclopedia of Communications, 3:226-229.

GOODY, J. \& WATT, I.P. 1963. The Consequences of Literacy. Comparative Studies in Society and History, 5:304-345

GRAFF, HJ. 1979. The Literacy Myth: Literacy and Social Structure in the 19th Century City. Orlando : Academic Press

GRAFF, H.J. 1985. Literacy. The Social Science Encyclopedia, 469-71.

GRAFF, H.J. 1987a. The Labyrinths of Literacy: Reflections on Literacy Past and Present. London Falmer Press.

GRAFF, H.J. 1987h. The Legacies of Literacy: Continuities and Contradictions in Western Culture and Society. Bloomington : Indiana University Press.

GRAHAM, W.A. 1987. Beyond the Written Word: Oral Aspects of Scripture in the History of Religion. Cambridge : University Press.

HARRIS, R. 1986. The Origin of Writing. London: Duckworth.

HA VELOCK, EA. 1963. Preface to Plato. Cambridge : Bclknap.

HAVELOCK, E.A. 1982. The Literate Revolution in Greece and its Cultural Consequences. Princeton University Press.

HAVELOCK, E.A. 1986. The Muse Learns to Write: Reflections on Orality and Literacy from Antiquity to the Present. New Haven : Yale University Press.

HAYNES, W.L. 1988. Of That Which We Cannot Write: Some Notes on the Phenomenology of Media. Quanerty Joumal of Speech, 74:71-101. 
HEATH, S.B. 1982. What No Bedtime Story Means: Narrative Skills at Home and School. Language in Society, 11:49-76.

HEATH, S.B. 1983. Ways with Words: Language, Life and Work in Communitics and Classrooms. Cambridge : University Press.

HILDYARD, A. \& OLSON, D.R. 1982. On the Comprehension and Memory of Oral vs. Written Discourse. (In Tannen, D., ed. Spoken and Written Language: Exploring Orality and Literacy Norwood : Ablex. pp. 19-33.)

HYMES, D. 1\%64. Introduction: Toward Ethrographies of Communication. (In Gumperz, J.J. \& Hymes, D. eds. The Ethnography of Communication. Washington: American Anthropological Association. pp. 1-34).

HYMES, D. 1975. Breakthrough into Performance. (In Ben-Amos, D. \& Goldstein, K.S., eds. Folklore: Performance and Communication. The Hague : Mouton. pp. 11-73.)

JOUSSE, M. 1990. The Oral Style. New York : Garland (Translated by E. Sienaert \& R. Whitaker)

KAPLAN, S.J. 1989. Communication Technology and Socicty. (I/ Phillips, G.M. \& Wood, J.T., eds. Specch Communication: Essays to Commemorate the 75th Anniversary of the Speech Communication Association. Carbondale : Southern Illinois Universily Press. pp. 205-234.)

KENNEDY, G.A. 1980. Classical Rhetoric and its Christian and Secular Tradition from Ancient to Modern Times. London : Croom Helm.

LENTZ, T.M. 1989. Orality and Literacy in Hellenic Greecc. Carbondale : Southern Illinois University Press.

LéVI-STRAUSS, C. 1974. Tristes Tropiques. New York : Athencum.

LORD, A.B. 1960. The Singer of Talcs. Cambridge : Harvard University Press.

LORD, A.B. 1987a. Characteristics of Orality. Oral Tratition, 2(1):54-72.

LORD, A.B. 1987b. The Nature of Oral Poetry. (In Folcy, J.M., ed. Comparative Research on Oral Traditions: A Memorial for Milman Parry. Columbus : Slavica Publishers. pp. 313-349)

LUKE, A. 1989. Basal Reading Textbooks and the Teaching of Literacy. Educational Policy, 3(2):163176.

MACKIE, R ed. 1980. Litcracy and Revolution: The Pedagogy of Paulo Frcire. London : Pluto Press.

MBITI, J.S. 1990. African Religions and Philosophy. 2nd. ed. Oxford : Heinemann.

MCLUHAN, M. 1962. The Gutenberg Galaxy: The Making of Typographic Man. Toronto : Universily Press.

NICKERSON, R.S. 1985. Adult Litcracy and Technology. Visible Language, 19:311-355

NOBLITT, J.S. 1988. Writing, Technology and Secondary Orality. Academic Compuring, :34-35, 56-57. Fcb.

OGBU, J.U. 1990. Cultural Model, Identity, and Literacy. (In Stigler, J.W.; Shweder, R.A. \& Herdt, G., eds. Cultural Psychology: Essays on Comparative Human Development. Cambridge : University Press, pp.520-541.)

OLSON, D.R. 1977. From Utterance to Text: The Bias of Language in Specch and Text. Harvard Educarional Review, 47:257-81.

OLSON, D.R. 1980. Some Social Aspects of Meaning in Oral and Written Language. (In Olson, D.R., ed. The Social Foundations of Language and Thought. New York: W.W. Norton. pp. 90-108.)

OLSON, D.R. 1988. Interpreting Texts and Interpreting Nature: The Effects of Literacy on Hermeneutics and Epistemology. (In Säljö, R., ed. The Written World: Studies in Literate Thought and Action. Bcrlin : Springer Verlag. pp. 123-138.)

OLSON, D.R. \& HILDYARD, A. 1983. Literacy and the Comprehension and Expression of Literal Mcaning. (In Coulmas, F. \& Ehlich, K., eds. Writing in Focus. Berlin : Mouton. pp. 291-325.)

ONG, W.J. 1967. The Presence of the Word: Some Prolegomena for Cultural and Religious History. New Haven : Yalc University Press. 
ONG, WJ. 1977. Interfaces of the Word: Studies in the Evolution of Consciousness and Culture. Ithaca : Cornell University Press.

ONG, WJ. 1982. Orality and Literacy: The Technologizing of the Word. London : Mcthuen.

ONG, W.J. 1986. Writing is a Technology that Restructures Thought. (In Baumann, G., ed. The Written Word: Literacy in Transition. Oxford : Clarendon. pp. 23-48.)

ONG, WJ. 1987. Orality-Literacy Studies and the Unity of the Human Race. Oral Tradition, 2:371-382.

ONG, WJ. 1988. Before Textuality: Orality and Interpretation. Oral Tradilion, 3:259-269.

ONG, WJ. 1990. Technological Developments and Writer-Reader-Subject lmmediacies. ( $h$ Enos, R.L. ed. Oral and Written Communication: Historical Approaches. Newbury Park : Sage Publications. pp. 96-125.)

PARRY, M. 1971. The Making of Homeric Verse: The Collected Papers of Milman Parry, edited by A Parry. Oxford : Clarendon.

RESNICK, D.P. \& RESNICK, L.B. 1977. The Nature of Literacy: An Historical Exploration. Harvard Educational Review, 47:370-385.

ROBERTS, C.H. \& SKEAT, T.C. 1983. The Birth of the Codex. London : Oxford University Press

SÄLJÖ, R. ed. 1988. The Written World: Studies in Literate Thought and Action. Bcrlin : Springer Verlag.

SANDERS, L. 1980 . The Tenth Commandment. London : Granada.

SCHMANDT-BESSERAT, D. 1977. An Archaic Recording System and the Origin of Writing. Syro Mesopotamian Studies, 1:1-32.

SCRIBNER, S. \& COLE, M. 1981a. The Psychology of Literacy. Cambridge : Harvard University Press. SCRIBNER, S. \& COLE, M. 1981b. Unpackaging Literacy. (In Whiteman, M.F., ed. Writing: The Nature, Development, and Teaching of Written Communication, vol 1. Variation in Writing Functional and Linguistic-Cultural Differences. Hillsdale : Lawrence Erlbaum. pp. 71-87.)

SLOAN, T.O. \& PERELMAN, C. 1986. Rhetoric. Encyclopaedia Britannica 15th. ed. Macropaedia, 26:803-810.

SMITH. A. 1986. On Audiovisual Technologies: A Future for the Printed World. (In Baumann, G., ed. The Written Word: Literacy in Transition. Oxford : Clarendon. pp. 171-192.)

STEIN, N. \& TRABASSO, T. 1982. What's in a Story: An Approach to Comprehension and Insiruction (In Glaser, R., ed. Advances in Instructional Psychology, vol. 2. Hillsdale : Lawrence Erlbaum. pp. 213-267.)

STEINER, G. 1985. Language and Silence: Essays 1958-1966. London : Faber \& Faber.

STOLTZ, B.A. \& SHANNON, R.S. eds. 1976. Oral Literature and the Formula. Ann Arbor : University of Michigan

STREET, B.V. 1984. Literacy in Theory and Practice. Cambridge : University Press.

STREET, B.V. 1988. Literacy Practices and Literary Myths. (In Säljö, R., ed. The Written World Studies in Literate Thought and Action. Berlin : Springer Verlag. pp. 59-72.)

STUBBS, M. 1980. Language and Literacy: The Sociolinguistics of Reading and Writing. London Routledge.

TAMBiAH, S.J. 1985. The Magical Power of Words. (In Tambiah, S.J. Culture, Thought, and Social Action: An Anthropological Perspective. Cambridge : Harvard University Press. pp. 17-59.)

TANNEN, D. 1980. A Comparative Analysis of Oral Narrative Strategies: Athenian Greek and American English. (In Chafe, W., ed. The Pear Stories: Cognitive, Cultural and Linguistic Aspects of Narrative Production. Norwood: Ablex. pp. 51-87.)

TANNEN, D. 1982a. The Myth of Orality and Literacy. (In Frawley, W., ed. Linguistics and Literacy. New York : Plenum Press. pp. 37-50.)

TANNEN, D. 1982b. Oral and Literate Strategies in Spoken and Written Narratives. Language, 58:1-21. 
TANNEN, D. ed. 1982c. Spoken and Written Language: Exploring Orality and Literacy. Norwood: Ablex.

TANNEN, D. 1988. The Commingling of Orality and Literacy in Giving a Paper at a Scholarly Reference. American Speech, 63:34-43.

TANNEN, D. 1989. Talking Voices: Repetition, Dialogue, and Imagery in Conversational Discourse. Cambridge : University Press.

TEDLOCK, D. 1983. The Spoken Word and the Work of Interpretation. Philadelphia : University of Pennsylvania Press.

TOELKEN, B. 1975. Folklore, Worldview, and Communication. (In Ben-Amos, D. \& Goldstein, K.S., eds. Folklore: Performance and Communication. The Hague : Mouton. pp. 265-286.)

TROLL, D. 1990. The Illiterate Mode of Written Communication: The Work of the Medieval Scribe (In Enos, R.L., ed. Oral and Written Communication: Historical Approaches. Newbury Park : Sage Publications. pp. 96-125.)

VAN DER LEEUW, G. 1964. Religion in Essence and Manifestation. London : Allen \& Unwin.

VANSINA, J. 1985. Oral Tradition as History. London : James Currey.

WARD, J.O. 1990. Rhetoric, Truth and Literacy in the Renaissance of the Twelfith Century. (In Enos, R.L., ed. Oral and Written Communication: Historical Approaches. Newbury Park : Sage Publications. pp.126-157.) 
